\title{
Digital Labour and the Use-value of Human Work. On the Importance of Labouring Capacity for Understanding Digital Capitalism ${ }^{1}$
}

\author{
Sabine Pfeiffer
}

University of Hohenheim and ISF Munich, Germany, www.sabine-pfeiffer.de

\begin{abstract}
On the face of its virtual and immaterial appearance, digital labour often is seen as a phenomenon of abstract work. Contrary to that common understanding, in Marx's theory the abstraction of labour derives from its historical development into a commodity, splitting human work as all commodities into use-value and exchange-value. Thus the process of abstraction is of economical logic, and not to be explained or characterized by the virtual and immaterial quality that is typical for the means and objects of digital labour. In his early work Marx differentiates between living labouring capacity (Arbeitsvermögen) as the use-value of human work and labour power as its objectified form to be exchanged. In the tradition of Marx's Grundrisse Oskar Negt and Alexander Kluge in Geschichte und Eigensinn pointed to the dialectical relationship between the use-value and exchange-value of labour, revealing how labour on its use-value side "contains and reproduces capacities and energies that exceed its realisation in/as commodity", extending the model of labour power "to a whole range of physiological, sexual, social, and national relations" (Negt and Kluge 1993a, xxxiii). While these qualitative and material as well as corporeal aspects of human work are still visible in industrial production processes, they seem to be vanished in virtual work environments. But, digital capitalism not only opens up exploitation to higher levels and new forms (e.g. Fuchs 2012; Scholz 2012), the relevance of human work and its use-value for capitalism becomes more concealed to the same degree as it becomes more significant. The article develops an analytical conception relying on Marx's dialectical distinction between the use-value (labouring capacity) and the exchange-value (labour power), and transforming it into an operationalized model that could be and has been successfully used for empirical studies of digital labour. Labouring capacity has three levels of phenomena: subjectifying corporeal working action, material means and objects of work (even in virtual environments), and the socially and physically experienceable face of globalised work organisation. This analytical concept of labouring capacity (Arbeitsvermögen; Pfeiffer 2004) is especially helpful to reveal the dialectics in digital work and its sources of value creation (Pfeiffer 2013). The article unfolds the theoretical foundations of the concept, and elaborates its potential to analyse digital labour.
\end{abstract}

Keywords: digital work, labouring capacity, dialectic, subjectifying work action, corporeality, and materiality.

Acknowledgement: The conceptual work on this paper is originated in the context of the COST Action 'Dynamics of Virtual Work' (IS1202) and was continued in the research project 'RAKOON_Innovation by active collaboration in open organisations' (Ref. no. 01FK13045); jointly funded by the German Federal Ministry for Education and Research (BMBF) and the European Social Fund (ESF) and supervised by the German Aerospace Center (DLR). Thanks to both anonymous reviewers and their critical thus supportive thoughts that helped to strengthen my argumentation and to improve this paper.

\section{Introduction}

The debate on digital labour/digital work seems to have reached a new all-time high as it is recently discussed broadly in social sciences (cf. Scholz 2012; Fuchs and Sevignani 2013; Huws 2014). Despite minor differences in the lines of argumentation, we see a consensus

\footnotetext{
${ }^{1}$ The term digital capitalism used heuristically here does not refer to one sphere of production, e.g. ICT, nor does it claim that all material resources or forms of labour and production are of no economical importance. For a typology on definitions of digital or informational society see Fuchs (2013) or Schmiede (2006), fostering the conclusion that we are confronted with a "unity of diversity of capitalism(s)" today. Schiller, who coined the term digital capitalism in adversary to the then popular New Economy emphasis (2000), stresses that capital stays at the "center of the political economy even as the market system was restructured to accept a profitable informationintensive orientation" (Schiller 2011).
} 
that work and labour are analytical terms of sustaining importance. Human labour remains the actual source of value creation in the Internet economy. The vivid debate though, points to a peculiar movement: while labour at its core is becoming more important as a source of value creation, on the manifestation level it seems to be fading from view (Pfeiffer 2013, 30): "Human labour remains quantitatively and qualitatively relevant for value creation in the Internet economy: On the one hand, its commodification takes on expanded forms; whilst on the other, more options open up for labour input beyond employment and exchange relationships or to use its results as commons."

Fuchs and Sevignani $(2013,237)$ stress the importance of Marxian labour theory and argue that the difference between labour and work still matters. For them labour is rendered as the valorisation dimension of digital work. The authors revisit the economically driven process of abstractification that Marx developed as the most important characteristic for all capitalistic labour. Fuchs and Sevignani deserve the credit for demonstrating how vital Marx's concept of work and labour still is: how work as an essential category is necessary labour, producing use-value in a concrete labour process; and, how many layers of abstraction are necessary to transform it into abstract labour as commodity, with a quantifiable exchangevalue $(2013,248)$. Thus far, there seems to be no need for analysing digital work differently than Marx would have done it, and in that respect I totally agree with Fuchs and Sevignani (and many others as well): The double character of work/labour that Marx unfolded is "alive and kicking", be capitalism digital or not. There is no need for re-inventing well serving analytical categories if we want to understand the economic function and movements that are specific for capitalism; there may are new options for and means of exploitation in a digital and therefore more globally organized capitalism, but the underlying logic seems steadfast.

Fuchs and Sevignani also look into digital work, which they understand, mostly as bare of material manifestations, be it body or be it objects. The digital quality in their definition comes out of a special form of organizing experiences, derived from brain, speech, and digital media. Following their further line of argumentation reveals three "dialectically connected" dimensions: cognitive work, communicative work, and co-operative work (Fuchs and Sevignani $2013,252)$. The subjects of these three working dimensions are single humans or groups of humans, their objects of work are experiences, thoughts or meaning; and their instruments of work are described as brain, or brain with mouth and ears; or a brain with mouth, ears and body. Finally, the products of work in their presented table also show relations ordered in an upward manner: cognitive work transforms experiences into thoughts, communicative work produces meaning out of thoughts, and in turn these meanings can be shared in co-operative work (Fuchs and Sevignani 2013, 252). The provided heuristic on digital work helps me to clarify the dimensions I think should be analytically elaborated further, and to specify the questions in due course that have to be asked and should be answered.

First of all, and again, I agree with Fuchs and Sevignani upon the feeling that work in digital times needs to be re-considered, although its use-value producing quality has not changed. Besides that consensus, the fact alone that some means, objects and processes of labour and/or work are more virtualized, digitised, or informatised than a couple of years before, does not convincingly justify to reinvent work as an analytical category. A pinch of unease creeps in here, that is best expressed by Ursula Huws, who criticised the emerging consensus "that the world as we know it is becoming quite dematerialised (or, as Marx put it, 'all that is solid melts into air')", and it became "taken for granted that 'knowledge' is the only source of value, $[\ldots]$ and any assertion of the physical claims of the human body in the hereand-now is hopelessly old-fashioned" (Huws 1999, 30). In that sense, I will follow Ursula Huws on her path into what she named the challenge of "re-embody cyberspace", making "visible the material components of this virtual world" $(1999,30)$.

In its core, this objective is tantamount to a dialectical endeavour. Hence, the second chapter challenges the too often to be seen approach of a dualism that is labelled as dialectic. As an example the concept of Scott Lash is critically discussed, which claims that in times of informationalisation, dualism comes to its end. This notion stands for common debates that non-analytically propose all theoretical terms of the past to be obsolete in the face of the shining brand new phenomenon of the Web. No better could the aim of the second chapter 
be characterized than in the words of Lefebvre: "But to define 'the new' by sifting out everything that distinguishes it from the old is not as easy as the dogmatists with their lack of dialectic used to believe. Our era is truly an era of transition; everything about it is transitory, everything, right down to men and their lives. The informed observer will be as struck as much by similarities as by differences, as much by the unity within contradiction as by contradiction itself. The one must not eliminate the other" (Lefebvre 1991, 50).

The main object of this paper which will be outlined in the third chapter is to develop an analytical conception relying on Marx's dialectical distinction between the use-value (labouring capacity) and the exchange-value (labour power) side of human labour, and transforming it into an operationalized model that could be and has been successfully used for empirical studies of digital labour. As we will see, labouring capacity has three levels of phenomena: subjectifying corporeal work action, material means and objects of work (even in virtual environments), and the socially and physically experienceable face of globalised work organisation. The third chapter will unfold the theoretical foundations of the concept and elaborate its potential to analyse digital labour, bringing materiality and the corporeal back in. The fourth chapter will summarize the key conclusions of this paper and offer some prospects on the potential of the concept of labouring capacity for empirical studies on digital work.

\section{Re-visiting Digital Work, Abstractification and Dialectics}

As the Internet continues to develop, we are exposed to a continuing stream of proclamations of novelty and socio-theoretical diagnoses of the times, from a variety of provenances, each based on the notion that the Web has introduced fundamental changes to existing paradigms. These concepts include the "informatisation of production" in the Age of Empire (Hardt and Negri 2000, 280-303), the new "terms of the economic transitions" beyond capital (Hardt and Negri 2009, 263-311), the notion of the "new economy" in Network Society (Castells $2000,77-100$ ), or the current thesis of a "new social operating system" in Networked by Rainie and Wellman 2012).

In contrast with prominent said positively tinged interpretations of the Web, other authors point to an expanded commodification. In these approaches, mostly from a critical perspective, the Web is clearly tagged as a place where interactive networking between people becomes a new object of commercial exploitation (Abelson et al. 2008, 110-11). Users are not primarily of interest as customers but themselves become merchandise (Fuchs 2011) and community experiences on the Web turn into an object of exploitation and source of capital accumulation (Fuchs 2012). These analyses reveal the fact that the core of many web driven business models is "to get everyone to work for free"; namely, all that sharing has a "dark side [...] that hits labour hardest" (Caldwell 2009, 161).

Elsewhere (Pfeiffer 2013) I tried to show how a web based economy needs an exact distinction between value creation understood as the actual process of producing new values; that is, values that do not exist prior to their production process, before the application of human labour. Value realisation, on the other hand, is the process by which the product that originated as part of value generation is valorised and successfully exchanged in the market for money or other value. In other words, it is about actually realising the already-generated value in the marketplace. This very abstract and generalised distinction will suffice for now. It is not new in the tradition of the economic labour theory of value. It is in this way, in particular, that the Marxist explanation of the economy understands value generation primarily as a material production process, in the course of which an equally material product is created by the exertion of human labour capacity. In this tradition, value realisation is conceived as a one-time, isolated act of exchange: as the transfer of goods from production to distribution. These definitions are ideal-typical, analytical characterisations, which Marx used in order to lay bare the nature of these processes in his political economy. Only in this way could he pursue his objective: to work out the importance of human labour as the crucial source of value added and hence of value creation. Ideal types and analytical distinctions, however, can never-and this applies to all schools of thought - be equated with empirical reality. The Marxian analysis pursued the nature of processes, intent on looking beyond manifestations 
(and their empirical variety). However, in applying Marxist theory the multiplicity of empirical manifestations has too often and for much too long been reduced to phenomena that are as close as possible to their intrinsic ideal type. The (mistaken) conclusion that has often suggested itself is that value can only be produced with material products and through industrial production, because added value is so impressively explained by them. In the same way, the importance of other areas of value generation has been underestimated for a long time, just like the value realisation processes, although there, too, human labour has also always engaged in creating value. Starting from this basic analytical distinction, I do not adopt the constantly recurring differentiation between production and information, which appears so frequently in the works cited above. The emphasis solely on the interactive or the cooperative is equally unconvincing, because it is precisely such stylisation of the importance of cooperation in work and cooperation as work a-historically as a new phenomena that makes it difficult for the Web-induced changes in the relationship between cooperation and work to be grasped analytically.

So far, both perspectives so to speak lack dialectical grounding for an in-depth critique. Here, too, it is a matter of deliberately focusing on the structurally concealed areas and qualities and to embark on a search for the inherent other in the everyday. This perspective is neither an end in itself nor a retreat into empirical minutiae, but rather the expression of a decidedly critical perspective. A critical and policy-relevant perspective will not stop on the level of analysing social conditions and their current variations of economically driven strategies. The critical (and consequently the dialectical) view describes not only the aims and functioning of what it wants to critique but looks for the "wrench in the machinery": It seeks out the places where processes do not run seamlessly, where they encounter resistance, and where subversive dealings with them develop; it looks for what escapes the subsuming logic per se; it searches for the inherent limits on the processes themselves, and it is therefore always on the lookout for starting points for alteration and opposition.

Lash (2002) declares the dualistic relationship between use-value and exchange-value to be obsolete, citing the increase in the immaterial thanks to digitisation. This does not appear to be convincing, for two reasons. First, capitalism, especially in its highly industrialised phase, alongside material goods has always produced the immaterial in the form of services, works of the intellect, information and entire systems of cultural scientification practices. Secondly, it remains unclear-because unsubstantiated-why Lash posits dissolution of this dualism for the information society: "But the logic of informationalisation is altogether different. Unlike the logic of commodification it is not dualist, but immanentist. It explodes and partly marginalise the exchange value/use value couple" (Lash 2002, 9).

Lash does not clarify how and why digitisation in particular can cause the dissolution of use-value from exchange-value; instead, he describes manifestations of this dissolving process: Namely, everything is now allegedly "dis-embedded"-actors, people, non-humans, and networks, cultural and material objects and, above all, also information. This analytical vagueness could be overcome by not conceiving the relationship between exchange-value and use-value as dualistic, but rather as dialectical-as laid out by Marx. It is worthwhile to differentiate clearly between dualism and dialectics. A dualism comprises two sets of facts or characteristics of a clearly and succinctly different nature but which are not opposed as such (e.g. fish and meat). Dialectics, in contrast, distinguishes dialectical unity from logical identity, dialectical from logical difference, and dialectical contradiction from logical contradiction.

Lefebvre explains that by work and leisure: their relation is "not a simple one: the two words are at one and the same time united and contradictory (therefore their relation is dialectical)" (1991, 29). As Joachim Israel develops (1979), dialectics comprises dualistic concepts; opposing elements within a totality are fundamental to dialectical thinking. The relationship between the opposing elements is therefore of an internal nature, a relationship Marx points out in his description of the separated unity commodities are constructed of: "So far two aspects of the commodity-use-value and exchange-value-have been examined, but each one separately. The commodity, however, is the direct unity of use-value and ex- 
change-value, and at the same time it is a commodity only in relation to other commodities" (Marx 1859b, 269-92). ${ }^{2}$

In contrast to a dualistic understanding, use-value and exchange-value indeed do not simply confront each other as oppositional, but simultaneously condition each other and combine inseparably in goods. In order to test the relevance of the dialectical method, in what follows I will assume an unbroken dialectical (not dualistically misunderstood) relationship between use-value and exchange-value and apply it-entirely in the vein of Lash's informationalisation-to information and knowledge. Beforehand, it will pay to reread the "inventor" of this dialectical relationship: While exchange-value, being a quantitative relationship, expresses a proportion (quantitative ratio) that makes the most varied use-values exchangeable, use-value itself encompasses the qualitative, the usefulness of a good: "The utility of a thing makes it a use value. But this utility is not a thing of air. Being limited by the physical properties of the commodity, it has no existence apart from that commodity. A commodity, such as iron, corn, or a diamond, is therefore, so far as it is a material thing, a use value, something useful. This property of a commodity is independent of the amount of labour required to appropriate its useful qualities. When treating of use value, we always assume to be dealing with definite quantities, such as dozens of watches, yards of linen, or tons of iron. The use values of commodities furnish the material for a special study, that of the commercial knowledge of commodities. Use values become a reality only by use or consumption: they also constitute the substance of all wealth, whatever may be the social form of that wealth. In the form of society we are about to consider, they are, in addition, the material depositories of exchange value" (Marx 1887c, 45-51).

If the decisive factor in use-value is its usefulness, which, moreover, is realised exclusively through appropriative use by humans, nothing argues against also applying this definition to goods that are not substantial-material. Thus, the use-value of a book is extracted only by reading it, of an image editing software only with specific use-i.e. in actually manipulating a digital image - and of a computer game by playing it. Still, we might be tempted to agree with Lash-"tons of iron" has such a seductively obsolete industrial society ring to it.

Every good potentially has use-value. At a given point in time, any good can have a certain use for a particular purpose, independent of whether the commodity body, to use Marx's term, is represented materially or immaterially. Realising the use-value that is potentially embedded in a good requires the expenditure of human effort: The use-value must be handled or processed, used up or used, consumed-ultimately, it must be appropriated in some form. It follows that the use-value is something that inheres potentially in every substantial representation of a thing but that it is realised only during the process of appropriation. This assertion is completely transferrable without alteration to digitised products also. The (seeming) non-substantiality of an operating system or a software application is not as immaterial as some authors would have it. Software is software is software. And this it is in a very specific manner; for example, as optimised for a certain type of processor, able to run on a specific operating system, etc. Software is software; it is not a car, nor a shirt, coffee pot or book. It harbours within it a particular purpose sphere, a potential usefulness that constitutes its usevalue. The use-value of a word processor is exploited in writing with it-however much I might exert myself, as a user I have as much chance of teasing out a 3D animation from a word processor as from a scripting language like HTML or a programming language not designed for 3D functionalities. In other words, nothing has changed in the fundamental Marxian assertion about use-value if we apply the concept to seemingly immaterial products-this is also why I do not call them immaterial but abstract-substantial. It holds true for both product types that the substantial-material and the abstract-substantial commodity bodies both register a potential use-value-so, for example, the possibility of riding on a motorcycle is its potential use-value or the possibility of writing texts is a word processor's potential use-value. Both commodity bodies have in common that the respective potential use-value cannot arbi-

\footnotetext{
${ }^{2}$ All citations of Marx in this article are to be found in the online version of the English MECW (Marx Engels Collected Works; http://www.marxists.org/archive/marx/works/cw/). Bibliographical details are each identified by the MECW volume, the specific work and/or chapter, the corresponding range of (offline) pages, and the according link.
} 
trarily be abstracted from the substantial-material or abstract-substantial conditions of the commodity body. Thus, we may indeed misuse both motorcycle and word processor but only within the framework of specific, given implementations that materialise very well in some fashion: "One and the same use-value can be used in various ways. But the extent of its possible application is limited by its existence as an object with distinct properties. It is, moreover, determined not only qualitatively but also quantitatively" (Marx 1859b, 269-92).

In addition, it applies equally to both commodity bodies that their potential use-value realizes itself exclusively in the framework of their use or appropriation. Hence, with respect to use-value, no difference of a fundamental nature can be detected between abstractsubstantial and substantial-material products. ${ }^{3}$ The relevance of use-value is salvaged into informational capitalism. Nevertheless, this does not necessarily prove yet that the usevalue/exchange-value relationship remains as intact dialectically. After all, compared with industrial society, a fundamental difference emerges concerning the production of commodity bodies carrying the respective use-values: While the potential use-values that are bound to substantial-material commodity bodies cannot be reproduced, but instead always require the production of a new commodity body, in the case of abstract-substantial commodity bodies the potential use-value is indeed reproducible, since only the data media holding the actual "immaterial" commodity body must be produced and no longer the commodity body itself. In this regard, the dialectical relationship between use-value and exchange-value must in fact receive renewed scrutiny.

Digital capitalism goes hand in hand with an increase in the quantitative importance of abstract-substantial versus substantial-material commodity bodies. Paradoxically, with the increasing exchange-value compatibility of the commodity bodies, their potential use-values become more conspicuous and important. We can trace this very clearly in the software example: The initial one-time production process (of programming) results in an abstractsubstantial commodity body (the code) that (through compilation and duplicability) turns out be especially exchange-value-compatible, because an increment in the goods to be produced for market does not require a further programming production process, just a download capability. This apparently total decoupling of use-value production from goods production at first glance looks like a capitalistic "wet dream": Make a one-time investment in the means of production and in live workers for the software programming production process; next, with a minimal investment in a duplication process, reproduce the use-value as much as desired and then realize an exchange-value in the market that far exceeds the cost of reproduction every time. In fact, this reproducibility of potential use-value can be interpreted as a new direction of movement within the dialectical relationship between use-value and exchange-value. However, it does not lead, as Lash asserts, to a dissolution or marginalisation of this relationship. Instead,_-and this is something that can only be understood dialectically-the seeming triumph of exchange-value as dominant leads to its opposite: Precisely this is what brings the importance of live work and the use-value side of their products and appropriative processes into sharper relief. The debates during the Open Source movement, involving demands for publishing the source codes or criticism of software patenting, exactly refer to this dialectical movement. Or, as Schmiede points out: "informatisation" should not be understood as "a linear tendency but a contradictory in itself" (2006: 334).

\footnotetext{
${ }^{3}$ Software products for example always have a substantial and physical-material basis, not only because material resources are necessarily applied to produce or to use them. The central point I want to highlight here is that the notion of substantiality addresses the material and bodily quality that immanently resides in all objects and instruments of work and in all human work they derive from. The distinction between physical and intellectual work neglects that even working processes of highly abstract thinking are embedded in human corporeality and in its ability of coping with and acting in a material environment. Marx would be the last to ignore that immanent material aspect as he emphatically analysed how abstractification driven by economic dynamics of capitalism conceals this material foundation of the human species.
} 


\section{Labouring Capacity as an Analytical Framework for Digital Work}

\subsection{On the Origins of a Dually Neglected Category}

Labouring capacity, as we will see can be conceptualized as the use-value side of labour, existent both, beyond paid labour and within. This qualitative core of human labour is dually neglected: First of all capitalism ineluctably disdains though uses and relies on this noncommodity side of human work. Secondly, in critical theory labouring capacity is often overseen and dismissed as romantic ideas of a younger Marx who overcame this weakness in his more elaborated and analysis of the Capital. As debates in Marxism lack a tradition of theorising this dialectical counterpart of labour power, it seems necessary to begin the unfolding of this concept by a clarification on its theoretical origins and semantic notions-an endeavour that unavoidably has to start with the terms work and labour. As mentioned above, Fuchs and Sevignani $(2013,239-49)$ already elaborated the distinction between both with special respect to the terms digital work vs. Digital labour, these debate here will just be briefly touched, and just to the extent that is necessary for understanding the argumentation to follow.

In Marxism usually labour is defined as "the capacity to do useful work which adds value to commodities" (Bottomore et al. 1998, 265). Adolph Douai, a pioneer German-American Marxist sees labour as the "opposite of capital", as "working force employed by capitalists and exploited by them", and therefore as "the enemy of human dignity and self-development" while he defines work as "human activity for the purpose of useful production" (Douai 1887, 1). Hannah Arendt defines labour as the never-ending necessity of producing consumable products, satisfying biological and physiological needs and fulfilling sustenance of life. In her view, not capitalism but the "industrial revolution has replaced all workmanship with labour, and the result has been that the things of the modern world have become labour products whose natural fate is to be consumed, instead of work products which are there to be used" (Arendt 1998, 124). Opposed to Marx's view the use-value of goods here seems to be attached to the realm of their origin, be it work (applying action resulting in work products to be used) or be it labour (fabricating labour products to be consumed). Similar to Arendt's distinctions, more current theories distinguish between work that is connected to art and creativity on one hand and mere production necessity on the other. In his book on gift, originally published in the late 1970s and actually re-discovered in the web-inspired debate on commons and a sharing economy, Lewis Hyde (Hyde 2007) discusses the notions of labour and work, but in a slightly different way: While welding on an assembly line, washing dishes, computing taxes or walking rounds in a psychiatric clinic is considered to be work, writing a poem, raising a child, developing a new calculus or resolving neurosis, and even all forms of inventions are seen as labours (Hyde 2007, 63-64). The line of distinction drawn here is that "there are labours that do not pay because they, or the ends to which they are directed, require built-in constraints on profiteering, exploitation, and-more subtly-the application of comparative value with which the market is by nature at ease. There are two points here, one having to do with the nature of work, the other with the commitment of the worker" (Hyde 2007, 138).

Although Arendt's and Hyde's definitions of work and labour do differ in perspective and wording, they share one central point: claiming there is a natural or deeper source of human working or labouring activity that somehow cannot be reached by market's logic and is evident in its untouched purity only beyond mere necessity needs, that is creative and artful or deeply caring activity. Both views try to save the not-market driven core of human work from the consuming logic of markets, exploitation or industrially organized forms of work. This is explicitly (with Arendt) or implicitly (with Hyde) opposed to a-as will be shown in due course-misunderstanding of Marx's theory of labour: To decipher contradictions in empirically real formations of capitalistic work, critical labour theory immanently needs a dialectical vis-à-vis to labour power even within capitalistic labour, not only as mere transcendental idea.

As he lays out in his earlier work, Marx defines labour in the sense of general life activity and human productivity. For him labour is the "living, form-giving fire; it is the transitoriness of 
things, their temporality, as their formation by living time" (Marx 1857, 333-400). Marx describes labour as man's interaction with nature as a process through which both, nature and man are changed and changing, a process of adopting and expressing the species, the "production of his active species-life" (Marx 1844, First Manuscript, Estranged Labour, XXIV) Opposed to that, work is the historically form of labour in capitalism, limited, distorted and deeply alienated. In the Grundrisse Marx uses the term of living labour capacity as a vis-à-vis to value and to labour (Marx 1857, 451-500) ${ }^{4}$ while in the first volume of the Capital we find the term of living labour-power (Marx 1887).

Initially let me introduce one major contribution to my line of thought, which is the idea of a "political economy of labour power" the German social philosopher Oskar Negt and film producer Alexander Kluge outline in their 1981 published three volumes titled Geschichte und Eigensinn. While their earlier book Öffentlichkeit und Erfahrung (Public Sphere and Experience) was translated in English in 1993 (Negt and Kluge 1993a), unfortunately their main work Geschichte und Eigensinn is not available in English. Jameson (1988) deserves the credit to have pointedly summarized the essentials of both works and thus opened it up to an international readership. As a German-American he also helps us to comprehend the notions of the authors' central concepts which are not easily transferred into another language starting with the "untranslatable word Eigensinn" and suggesting to render it with "self-will" (Jameson 1988, 158). Coping with the ideas of Negt and Kluge offers much more challenge than just that of an adequate translation. As Jameson highlights, the "originality" and "utopian effort" of both authors lies in producing a "discursive space of a new type", addressing the necessity of creating a terminology, a kind of new "public language" that corresponds to "forms and experiences" that do not yet exist (Jameson 1988, 157). This is especially true for the term that plays the main role in my line of argumentation here: the German word Arbeitsvermögen, to which Negt and Kluge are referring in the first volume of Geschichte und Eigensinn (1993b, 87-220), and which is translated in Public Sphere and Experience as living labour power, while Jameson sticks mostly to the term labour capacity.

One of the main issues of Negt's and Kluge's book is-as Miriam Hansen puts it in her forward-"whether and to what extent experience is dis/organized from 'above'-by the exclusionary standards of high culture or in the interest of property-or from 'below,' by the experiencing subjects themselves, on the basis of their context of living" (Negt and Kluge 1993a, xxxi).

Although each worker has "his own experiences", the "horizon of these experiences" forms a unity of the "context of living" (Lebenszusammenhang): "This context embraces both the ladder of production of this worker's commodity and use-value characteristics (socialization, the psychic structure of the individual, school, the acquisition of professional knowledge, leisure, mass media) as well as an element inseparable from this, namely, his induction into the production process. It is via this unified context, which he 'experiences' publicly and privately, that he absorbs 'society as a whole', the totality of the context of mystification" (Negt and Kluge 1993a, 6). The use-value side addressed here is what my argumentation will point to. In a footnote the authors exemplify how relevant the sensual side of the context of living is, how the "sensual presence" of this totality Negt and Kluge define as the public sphere of production "is internalized by human beings" (1993a, 13).

The mode for this internalisation process in the sense of Negt and Kluge is experience, both the result and the actor of this process is what they call "living labour power" and in German define as Arbeitsvermögen. Living labour power is formed by primary socialization in the family, and over the whole life course, it can "neither be generated nor sustained without detours, without a qualitative intensification of biographical stages of development" (Negt and Kluge 1993a, 21, original emphasis).

One central claim of the authors is that experience and living labour power is genuinely qualitative-although applied to and developed by experiencing objective structures and their-more or less-material representations. Experiences can "become commodities", they

\footnotetext{
${ }^{4}$ The two major English translations of the Grundrisse by Penguin (Marx 1993, 161) and the MECW cited above both use the term of living labour capacity.
} 
can be "reduced to a common denominator", they can be generalized - but they still "are produced as qualitative moments" and "lack[ ] the commensurability of commodity relations" (Negt and Kluge 1993a, 44, original emphasis). While the dialectical relationship between labour power and living labour shines through here, a footnote guides us deeper into the core of the authors argumentation: Therefore, "[...] labour power is, on the one hand, merely an object as the object of relations of production, while, on the other, it is simultaneously a subject in that it is living labour. Its subject quality becomes an object by way of its being subsumed beneath the power relations of the bourgeois public sphere" (Negt and Kluge 1993a, 59 , original emphasis).

Negt and Kluge focus on how societal change is thinkable given the alienated and alienating totality of capitalistic society. Although their argumentation following that direction is as actual as ever especially in our so called networked society, my main concern aims more to the empirical phenomenon of how living labour and labour power inevitably intertwine at the work site and what contradictions derive from that. Negt and Kluge offer some inspirations here that need to be elaborated in due course. For example as they stress how "labour power found within an individual" in advanced capitalist industries is "simultaneously mobilized and disqualified" (Negt and Kluge 1993a, 170, original emphasis), how there would be no use "for individuals whose behaviour is reduced to mere reactions", and how therefore capitalism "cannot avoid dirtying its hands with human beings". As Negt and Kluge consider this to be an immanently vulnerable point of capitalism and a source of its "extreme instability" (1993a, 185-86), I want to follow that path and explore how this dialectical drama between labour power and living labour capacity could be analytically framed, and-on that conceptional basis-be studied empirically.

For Negt and Kluge workers will have to gain consciousness about the use-value side of their labour power "which like every use-value is submerged without a trace in the quantitative exchange categories of capitalism. The specific nature of this kind of commodity has consisted in the fact that beneath the cloak of things lay a relation between human beings, that beneath the quantifying crust there was a qualitative, living core" (Negt and Kluge 1993a, 255-56). From my social scientist's point, an admittedly humble contribution is to lay bare this qualitative side, to excavate this living core in real world working environments. What Negt and Kluge claim to be a coming to mind the worker has to reach, could qualify as a guideline too for empirical research in sociology of work: to "recognize the machinery [the worker] encounters as what it is in reality, namely, objectified dead labour" and to "be able to perceive the contradiction between labour power as a commodity and [...] living labour (Negt and Kluge 1993a, 256).

In a similar approach to Negt and Kluge, other authors also pay attention towards the qualitative side of labour, referring to Marx earlier works, and, again, have to tackle finding the right expressions. Gulli (2006) directly addresses potentially arising complications by his synonymous usage of living labour and labour, but thus clarifies: "It must then be said immediately that the word 'living', which apparently qualifies 'labour,' is such a qualifier only from a grammatical, not an ontological, point of view. 'Living,' in the expression of 'living labour,' does not address the 'how' or 'which' of labour, but it is the most essential constituent of its 'what,' of its substance." Accordingly Gulli $(2006,1-2)$ asks: "In fact, how could labour be 'not living'?" Gulli also works with further synonyms like "capacity to work" or "capacity to labour" (e.g. 2006, 96 and 130). For Negri $(1991,68)$ terms like "capacity to work" are too "undifferentiated" as for him the worker's "capacity for labour" is a "creative force" that, although "subsumed by capital under the appearance of an equal exchange relation" (Negri 1991, 79), stays a "subjective power (potenza)" (Negri 1991, 70). The elaborations of both Gulli and Negri try to grasp the dialectical relation between the exchange-value and the use-value side of human labour also in terms of subjectivity and objectivity: Negri discovers with Marx a "dialectical development of an exceptional intensity" and argues against a mere natural or humanist misunderstanding that reduces use-value to a "residue or an appendage of capitalist development" (Negri 1991, 70). In contradiction to that Negri claims that the power of living labour, the potenza is irreducible $(1991,133)$, and Gulli emphasizes the interwoven contradiction in pointing out that this subjectivity is "in itself an objective capacity" $(2006,17)$. 
Beyond the differences in language-starting with the problem that German uses Arbeit for both labour and work - the discussion reveals major problems in finding appropriate terms: Negt and Kluge stressed the fact, that a quality is addressed that points towards a societal sphere that per se could not be of existence in capitalism. Gulli and Negri are coping with the verbal limitations one experience in the attempt of describing deeply dialectical relations. All said authors elaborate on the heritage of Karl Marx who thankfully initiates all those thoughts in his earlier writings thus stubbornly refuses to clearly distinguish between both sides of human labour throughout his oeuvre. Only in Grundrisse Marx explicitly uses the term labouring capacity, describing it as "a resource in the bodiliness of the worker" that "contained in his mere vitality", the "possibility of value-positing activity", and a "creative power" surrendered to capital by the worker (Marx 1857, 322-23). And still, while the Grundrisse since their introduction by Marcuse again and again have been considered a key to "an understanding of Capital and of Marx's theoretical project as a whole" (Musto 20080, i) the term of labouring capacity seems to be widely neglected in current theoretical debates. Maybe that has to do with the as often found as often opposed diagnosis that Marx in his earlier writings "drew on a romantic tradition" (Lash 1984, 28). Romantic or not, Lash elaborates aspects of the Marx concept of labouring capacity that have not been as clearly stated by all other hitherto cited authors: According to Lash, Marx speaks "of a series of species capacities or powers which correspond to human needs. He did not, as did rationalists and the mature Hegel, privilege the cognitive capacity; nor did he, like Kant, privilege the moral capacity. But he spoke, as well, of aesthetic, sexual, and labouring capacities, and a capacity of interpersonal relations. The labouring-capacity became labour-power in his later work. But although labour power is a force of production-and hence is attributed theoretical primacy-no doctrinal primacy of the labouring capacity is, therefore, entailed" (Lash 1984, 28-29). Lefebvre cautions against an over- else underestimation of Marx's early writings as these would "contain great riches, but riches still confused, riches half mined and scarcely exploited" (Lefebvre 1991, 80). By revitalising the notion of labouring capacity, Negt and Kluge began just that, in spelling out labouring capacity as an analytical term apt for empirical research of today's digital work, the next chapter follows that path.

Even Engels was more than concerned with the challenge of translating Marx's work appropriately. His earnest worriedness is expressed in a short text titled "How not to Translate Marx". Unfortunately the English translation (Engels 1885) of this text is extremely shortened and lacks all the clarifying examples Engels quotes, scornfully roasting one Mr. Broadhouse who-in Engels' eyes-epically failed in translating Marx: "Marx is one of the most vigorous and concise writers of the age. To render him adequately, a man must be a master, not only of German, but of English too. [...] Powerful German requires powerful English to render it; the best resources of the language have to be drawn upon; new-coined German terms require the coining of corresponding new terms in English" (Engels 1885). The German original text (Engels 1975, 229-237) also refers to one central question that touches the category that is essential for my argumentation here: living labour or living labour capacity. As one major example for a twist from German sense to English nonsense ("Verdrehung von deutschem Sinn in englischen Unsinn"), Engels talks about the dual character of work, unquestionably one of Marx's most excellent discoveries. While German knows one word (Arbeit), English distinguishes between work and labour, and Engels clearly opts to use this distinction consequently: work as specific producer ("Erzeugerin von Gebrauchswert") of use-value versus labour as general producer of value ("Erzeugerin von Wert"; concrete work vs. abstract labour; technical work versus economic labour. As my intention is just to reveal the importance of the use-value side of work within alienated labour, on first glance it seems more than evident that, in following Engels' advise, I should stick to the notion of working capacity. But there are at least two aspects that persuade me to use labouring capacity instead: First of all, working capacity is an established technical term in physics, and there is no need to further interdisciplinary misunderstandings without good reasons. Second of all and of much more importance, the English version of Marx's earlier works-especially the Grundrisse-do use labouring capacity or living labour capacity, and Marcuse's introduction to said Marx's early works (Marcuse 1973) explicitly discusses labour (not work) beyond its 
economic reductions. Following this traditional path, labouring capacity stays my term of choice. The reason for that is not to fall for a Hegelian trap, that could misleadingly interpret labouring capacity for work as such, meaning as work in its ontological and anthropological quality. Labouring capacity as we will see later, on one side is deeply connected to that underlying genuine human capability, but its phenomenon labouring capacity appears in a historically concrete form, derived from as evenly historically forms of the division of labour. What will be conceptualized in this paper and what will be made empirically evident therefore is the qualitative, use-value side of labour, the manifestation/appearance of work not its being/essence.

\subsection{The Dialectical Drama and its Stage Setting: Three Levels for Analysing Digital Work}

If sociological analysis is to stop summoning up the ever-recurring and long-known or to get off the roller coaster of technology euphoria and disappointment, it is necessary to clear up analytically which qualitative changes accompany the digitisation of work. Sketching such an analytical concept starts out quite trivially with the question of what digitisation impacts, to which the answer at first sounds equally trivial: the societal organisation of work, on the one hand, and, on the other, the subject doing the work.

Like every other commodity, human labour, as soon as it appears as a commodity, also turns out to be "a very queer thing, abounding in metaphysical subtleties and theological niceties" (Marx 1887, 81-94). For, even as labouring capacity is made feasible initially by labour power's commodification, it also mutates under its influence into "something transcendent" (Marx 1887, 81-94); translated from the German version, the meaning is closer to "a sensual transcendental thing". Just as the dialectical pairing of use-value and exchangevalue forms the dualistic character of goods, labouring capacity and labour power are the dialectical expressions of the dualistic character of the subjects that offer their labour power in the marketplace. This dialectical juxtaposition of labouring capacity and labour power connects it to the "political economy of labour power" (Negt and Kluge 1993b, 87-220): Namely, through the contrast of subjective production of labour power on the one hand and its objectification as a function of the wage labour process on the other.

The dialectical bundle of labour power and labouring capacity within the subject can only be severed analytically, not empirically. Empirical capture of both sides will therefore always run up against boundary areas, grey zones and shoals. Capturing as precisely as possible both the dialectical motion of the two toward each other as well as labouring capacity and labour power individually requires two things: an analytically exact distinction between the concepts and their collective investigation empirically. One-sided focus on labour power negates the qualitative aspects of human labour that it conceals. Single-minded focus on the labour capacity category distorts the view of the aspects compatible with exchange-value. A critical perspective will only emerge from looking at both of them together as well as at the dialectical relationship between them.

Labouring capacity is at once process and product. As the latter, it has invariably assumed form in the subject as well as outside it, and in this sense it has assumed material form. To the labouring capacity belong all qualities that systematically elude an objectification, while the capacity and potential, which can be objectified and formalised and hence prove to be amenable, at least potentially, to a power or control grasp of capitalistic exploitation, can be assigned to labour power after the successful transformation-but then and only then. Only when the dividing line is laid alongside objectiviability and formalisability does what is genuinely autonomous in labouring capacity remain visible. This is not about the distinction between what was already formalised and objectified and what is yet to go through this process - for example, as a result of future digitisation phases.

Labouring capacity and labour power are two fundamental aspects, each undergoing historically conditioned change and each behaving in a dialectical relationship to each other that can only be separated clearly into quantitative and qualitative components analytically. Analytical separation and empirical focus of this dialectical process are what first makes it possi- 
ble to expose the contradictions that run through society and the individual subject respectively. Out of the inherent qualitative increment of labouring capacity with respect to labour power and, conversely, the quantitative, formalising dominance of labour power with respect to labouring capacity emerges a dialectical movement that is characteristic of a capitalistically constituted society. As a result, labour power is always the abstraction of labouring capacity, which, however, always eludes complete abstraction. But both are in motion: The formalisability and abstractability-that is, the imprinting potential of the process that transforms labouring capacity into labour power-grow in line with the development of productive forces, while simultaneously labouring capacity differentiates itself qualitatively, spreads, partially dies off, but permanently renews on a new level.

Hence, on the subject level labouring capacity and labour power in their inherent dialectical entanglement are determined to be the key levels for the analysis of digital work. An indispensable precondition for empirical analysis on the subject level is the-for the subject, palpable-form determination in which its labour power and its labouring capacity find application, in which qualitative capacity forms and expends itself on the one hand, and, on the other, is quantitatively appropriated, transformed and economised; in short, the relevant formation of the social organisation of labour or the organisation of labour in its broadest sense. This is not just the stage on which the permanent "dialectical drama" (Lefebvre 1991, 169) between labouring capacity and labour power plays out in the subject, but, at the same time, it also forms the structural framework within which social relationships and their interaction with artefacts represent themselves.

The organisation of work to which the subject is tied is the slice of world most likely to be definable and nameable by the subject for appropriation during the work process and within which the specific structural conditions of permanent labour capacity are formed and partly transformed into labour power. Labour power's transformation, use and exploitation, just like the formation, expenditure and sedimentation of labouring capacity, cannot be conceived of independently of the stage setting that surrounds them and, so to speak, of the stage equipment to be utilised. The analysis of what is happening on the stage itself, narrowly focused on the protagonists labour power and labouring capacity, remains incomplete, unless the preformation parameters surrounding them-which they are ultimately also responsible for staging, i.e. for designing-are included in the analytical view. The subject-oriented analysis of informatised work thus includes in an integrative manner the organisation of work as a third level of analysis, in addition to the dual consideration of the labouring capacity and labour power dialectical pair. While the categories of labour power and labour organisation are, so to speak, a proven stock in trade of labour sociological analysis, rediscovery of labouring capacity as a vital and viable category of contemporary labour sociological analysis calls for a deeper look.

When labour power is interpreted as the subject's commoditised side, then structurally the subject alone cannot form its dialectical pole, which must move instead on the same level as its dialectical counterpart and therefore is situated in the labouring capacity. If we interpret the phenomena that are commonly taken as a subjectification of work, even as a result of a specific, historically achieved degree of complexity of the productive forces, which in turn yields an increased requirement for appropriation by the working subjects, then this signifies qualitatively a new need for a strengthened expenditure and exploitation but also the new formation of labour capacity. Particularly with digital work, which, to a special degree, requires the appropriation of a conglomeration of substantial, abstract and socially objectified, highly-complex work, labouring capacity therefore moves into the gravitational centre of the analysis as the qualitative, use-value side expression of human labour and as appropriation to have assumed form in the subject. Labouring capacity as appropriation that has assumed form is only observable in the context of the appropriation concept itself. Appropriation is always appropriation of world and thus not only of substantial-material (or also immaterial) objects and instruments of labour, but of an ensemble of social relationships, i.e., also affiliations, organisational forms, communication behaviours, etc. The qualitative and social essence of work is displayed in labouring capacity; in contrast, labour power is always already an abstraction from this process. Labouring capacity encompasses all the capabilities that 
are needed for the confrontation with world-i.e. for appropriation processes in the broadest sense-and that renew, convert, and transform in its course: The comprehensive forming and application of the senses, living working knowledge with its objectifiable (but not yet objectified) and non-objectifiable shares of experiential knowledge and, finally, capabilities of the situational concretising application of theoretically-grounded knowledge or of theoretically-grounded procedures and methods.

The more complex the world that is to be appropriated, i.e. the more dead, objectified labour, the more complexity of social affiliations and relationships are in it, the more expenditure and formation of labouring capacity is required in the appropriation process. But capital needs this qualitative aspect of living labour all the more: Human labour as producer of incremental value foremost had and has a quantitative meaning; the meaning of human labour as precondition for appropriation of highly developed productive forces is, and increasingly becomes, a qualitative one. That the organic composition of capital leads to a relative increase in dead labour not only has quantitative economic consequences, but also subjectrelated and socially qualitative ones: It yields an increasing necessity of appropriative activities (i.e. expenditure/formation of labouring capacity) for mastery in dealing with more complex, accumulated dead labour, because an increment in accumulated, objectified labour no longer is just an increment of machinery, but even more an increment in complexity and abstraction levels-a process to which digitisation has made and will continue to make a decisive contribution.

"A machine which does not serve the purposes of labour, is useless. In addition, it falls a prey to the destructive influence of natural forces. Iron rusts and wood rots. Yarn with which we neither weave nor knit, is cotton wasted" (Marx 1887, 187-96). And, we should add, digitised knowledge that is not utilised in real time obsolesces. The objects that Marx enumerated can be replaced without difficulty by more current, increasingly more relevant-hence in part also less substantial-materially represented-means of production. Software that is not updated loses compatibility or capability for running on suitable hardware but the rest of the quote points to the undisputed relevance of the core point to be made: "Living labour must seize upon these things and rouse them from their death-sleep, change them from mere possible use-values into real and effective ones. Bathed in the fire of labour, appropriated as part and parcel of labour's organism, and, as it were, made alive for the performance of their functions in the process, they are in truth consumed, but consumed with a purpose, as elementary constituents of new use-values, of new products, ever ready as means of subsistence for individual consumption, or as means of production for some new labour-process" (Marx 1887, 187-96). The artefacts, i.e. the means of production and products, may have changed their outward forms in the course of digitisation, but the function of living labour in calling them into existence has lost none of its relevance-quite the contrary.

\subsection{Corporeality and Substantiality in the Era of Digitisation}

From the concept of labouring capacity developed up to this point inevitably emerge the phenomenal levels that concretise this concept, for labouring capacity always forms and expends itself in relation to an object of labour as well as in handling certain labour means; and is not, after all, a specific form of labour action and of the utilised and the emerging, living labour knowledge nothing more than the outward form of that which was designated as the formation and expenditure of labouring capacity? Labour object, labour means and labour action-here, in their deliberately chosen relation to the analysis level of labouring capacity, in each case with special emphasis on their respective qualitative use-value sided aspectstherefore also form the necessary triad on the empirical phenomenal level of informatised work.

The understanding posited here of labour object and labour means and the specific interpretation of labour action aims at their respective qualitative, use-value sided aspects as seen from the perspective of labour capacity referred to at the start. With that, they are assumed generally to have substantiality or corporeality, even when labour object and labour means do not in reality present themselves as substantial-material and when labour action 
cannot be grasped corporeally in the traditional sense of physical-manual work. After all, the division into mental and physical work is not just real, from a categorical point of view the expression of the dominance of exchange-value over the use-value side of human labour is concealed by labouring capacity. The analytical separation of labour object and labour means also draws on Marx: "An instrument of labour is a thing, or a complex of things, which the labourer interposes between himself and the subject of his labour, and which serves as the conductor of his activity. He makes use of the mechanical, physical, and chemical properties of some substances in order to make other substances subservient to his aims. Leaving out of consideration such ready-made means of subsistence as fruits, in gathering which a man's own limbs serve as the instruments of his labour, the first thing of which the labourer possesses himself is not the subject of labour but its instrument" (Marx 1887, 187-96).

If we imagine electronic and information technological characteristics added to the mechanical, physical and chemical characteristics referred to in the quote from Marx, it not only highlights the unbroken relevance of this distinction. It also becomes clear in what follows why we can tie to the Marxian distinction between the instruments of labour and the actual object of labour and why a clear analytical division between instruments of labour and object of labour achieves heightened significance, particularly with an increasing degree of digitisation.

A concept of object that clings to sensory experience, and thus, in the final analysis, to a somehow generated material substantiality, seems-particularly in the context of the current discourses on digital work-at first glance to be obsolete. However, the actual labour object as empirical phenomenal level of labouring capacity possesses neither compellingly materialsubstantial characteristics nor is it entirely free of them. Although both have a materialsubstantial core (see above), empirically we find material-objectified labour (physical-material products of all kinds) as well as immaterial-objectified labour (e.g. ideas, inventions, software, program code). The actual object that digital labour relates to can for one have product traits in the sense of material- or immaterial-objectified labour. However, it can also relate to the same degree to processes of labour objectification, which, in turn, can once again have a material (production processes, installation procedures, etc.) or immaterial (e.g. high-level project management) character. Ultimately, the actual object of labour can also consist of processes that relate to corporeal subjects (e.g. a hairdresser's customer) or non-corporeal subjects (e.g. in B2B services), and immaterial processes can certainly exhibit a social objectified character.

Digitisation can have the most varied effects on the actual object of labour-or none whatsoever. To determine this with exactitude is always the task of the analytically sharp empirical eye. Thus, the labour object can be displaced by digitisation, or the degree of being able to experience it with the senses can change. Usually a reduced ability to experience can be verified though the additional digitisation levels; however, particularly in the development of future technologies, expansions of experience are conceivable. The actual object of labour is empirically not immediately obvious and is not susceptible to being derived causally from a particular form of activity or a formal labouring task. For one thing, it is constructed subjectively and sensorial re-contextualised, but in so doing does not arbitrarily abstract from the "substantiality" of the work object, however it may present itself. It can be product related objectified labour as easily as a process of objectification. In the abstract, it is materialised and objectified, but concretely it can also prove to be immaterial.

Any distinction between industrial and digital capitalism that refers only to the material or to the non-material resources that seem to be the foundation of value generation as soon as human labour is applied comes in short handed. Immaterial work objects, be it software code or a concept for change-management, often conceal their material and substantial core, e.g. a specific use in "real life" that this software code will make possible for a specific group of users, or the implementation of team work for a specific group of workers in a given factory. On the contrary, there is no and never has been any material work object that derives only from physical work and material resources and lacks any mental planning or intellectual foundations or could not be used or be the bases for immaterial purposes. The core difference between industrial and digital capitalism much more lies in the questions that have to 
be asked: With new forms of digital production and consumption, with the increasing importance of digitalised objects and instruments of work, and with the decline-at least in some national economies-of physical and industrial labour, with all these phenomena we see and explore empirically: Do we find new modes of exploitation? Do we find realms newly or further occupied by economic logic? And, are there new contradictions arising, even of a new quality? Given we answer these questions of and on with a resolutely or at least hesitant Yes, we have some evidence to call capitalism digital. As capitalism, and all other thinkable forms of economic systems that is, will never be digital in whole, but will always have to include agricultural and industrial spheres of production and consumption, critical social sciences also have to search for new or strengthening contradictions between these three spheres, and also have to explore how digitalisation is infused to and by that changes the modes of agrarian and industrial production. The concept of labouring capacity is meant to support the analysis of the ambivalent and heterogeneous varieties of phenomena we observe at today's work place. As the analytical dimensions of instruments and objects of work could not be fully understood without digging into the substantial core of human labour, empirically observable as work action, the next chapter follows that direction.

\subsection{The Missing Link: Subjectifying Work Action}

In whatever manner the instruments and objects of labour concretise themself, they most likely be empirically determined if we follow their targeted direction, i.e. with reference to the labour action directed toward them. Marx's concept of sensuality (Marx 1844, 326-348) is linked in a very specific, intentional way with the human senses and their practical application, because, according to Marx, only "with all his senses" does the human affirm itself in the objective world (Marx 1844, 293-306) and "eye and ear" are the "organs which take man away from his individuality and make him the mirror and echo of the universe [...]" (Marx 1842, 132-181). The human senses and their practical application in sensory activity, according to Marx, perform a specific function in appropriating the world, and therefore it seems especially obvious on the phenomenal level of labour action to choose a concept that not only sheds light on the use-value aspect of labour action but also pays special attention to the senses: the concept of subjectifying work action (Böhle 1994, 209). Skills of this kind have been receiving neither practical nor systematic consideration and are regarded as tacit skills in most cases. The negation reaches further and hints to one important dilemma: "Although the criteria identified with the model of skilled work stress responsibility, individual initiative and creativity, they largely eliminate subjective factors such as emotions, sensations or impressions derived from personal experience. These may have significance for individual motivation and subjective satisfaction, but for the 'correct' dealing with technical working material and an efficient, goal-oriented mastering of working demands they are perceived as disruptive and the cause of errors" (Böhle 1994, 209).

In German industrial sociology since the Eighties the concept of subjectifying work action has been trying to define categories that describe and study empirically this overseen qualities of human labour, qualities of experiential, tacit and informal skills that are so difficult to define. One of the first studies conducted on basis of said concept revealed that skills and qualifications based on empirical knowledge and individual capabilities, such as a feeling for machines and materials, continue to play an important part in a digitized work environment, empirically shown first by work with computer-controlled machines (Böhle and Milkau 1988).

This proves to be particularly compatible with the empirical capture of labouring capacity because, like it, it persists in an idiosyncratic, non-formalisable moment. In this acknowledgment of resistance is revealed, besides the strong emphasis on sensory activity, an additional chance to bridge the empirical concepts of subjectifying work action and the analytical concept of labouring capacity. It emerges clearly why subjectifying work action can be interpreted as a phenomenal level of labour capacity-and, correspondingly, objectifying work action as a phenomenal level of the labour power analysis level. Thus, there already exists in the subject-oriented sociology of labour a conceptually and empirically oft-validated concept that can be adapted for analysing the empirical phenomena of labouring capacity. 
The concept understands experience neither as basically inferior to theoretical, scientifically grounded knowledge, nor sees it as a quality to be completely replaced by the latter. Subjectifying work action is of great significance as an autonomous form of action and knowledge both for planning and practical action as well as for creative, innovative processes that form the basis for coping with unforeseen circumstances (Pfeiffer 1999). But an understanding of experience in this sense merely as a set of experiences, which have been acquired, is not sufficient. The perspective of having experiences also refers to a given moment and situation and to specific action methods used to tackle concrete situations. The concept includes four dimensions of human work action (Böhle 1994, 209): sensorial perception, thought, action and relationship.

All four dimensions do appear as objectifying and as subjectifying. Both modes have different qualities, and they are entangled in each other in every work-related action. They meet the criteria that are considered to be a relationship of dialectical quality: objectifying and subjectifying modes of action are internally contrary to each other on all four dimensions, thus they are deeply intertwined. Therefore the objectifying dimension covers what we usually associate with work in terms of exact and objective perception, logical thinking, rational and sequential procedures, all combined with an unemotional matter-of-fact relationship with the environment. Subjectifying work-related action, by contrast, is a simultaneous and complex sensory perception that takes place via all senses and body movements and is not detached from subjective feeling. It goes beyond an orientation to precise and clear-cut features towards handling more diffuse and stratified sources of information. While a distinction between these four aspects is possible in theory, in the reality of work-related action they are not separable. Analytically the subjectifying dimensions can be described and thus empirically collected as:

- Physical and sensorial perception;

- Associative and intuitive thought;

- Intuitive and dialogical action;

- And an empathetic relationship towards one's environment (persons, tools, and technical systems) or: the objects and means of work (Böhle and Milkau 1988, 239-40).

In the most recent sociological discussions this layer of working action is considered to play an increasing role in all kind of high-tech production. As automation and digitisation produce a growth of complexity and insofar further uncertainties and imponderables employees have to cope with in their everyday working life (Böhle 2011). These phenomena, not to be determined precisely, call for skills, abilities and a kind of knowledge, which can at least partially be characterized as experiential or subjectifying. Subjective experiences and feelings - such as intuitive action, sensory perception, associative, and intuitive thought, forming an interactive context-are acknowledged as an important basis for mastering complex high technology. While first studies focused on the quality of subjectifying work action in material work sites like production in manufacturing or the automotive and chemical industry, more recent research reveal the occurrence and importance of subjectifying work action within more digitized and so called immaterial work environments, e.g. in service work (Böhle 2013), in virtual forms of information-broking (Pfeiffer 1999), innovation work (Pfeiffer et al. 2010a), or assembly work in highly computerised Toyota Productions Systems (Pfeiffer et al. 2010b). The design of work processes and organisation, the construction of machines and their control units, the usability of interfaces and even concepts for qualification and models of learning mostly focus on the objectifying modes of work action. Although subjectifying work action qualities are widely "ignored and neglected" (Pfeiffer 1999), it is "not denied that experiential knowledge has practical uses. However, in the objectifying model, experiential knowledge is viewed as something that basically can be improved, enlarged and ultimately replaced by scientifically grounded knowledge. Thus experiential knowledge is seen only as a preliminary step for theoretical, scientifically grounded knowledge. In this context experiential knowledge is equated with 'everyday knowledge' or 'rules of thumb"' (Böhle 1994, 209). The table below combines all aspects and dimensions of labouring capacity, giving a comprised overview. 


\begin{tabular}{|c|c|c|c|}
\hline \multicolumn{3}{|c|}{ Digitalisation takes effect on... } & \\
\hline \multirow{2}{*}{ Societal division of labour } & \multicolumn{2}{|c|}{ Working subject } & \\
\hline & \multicolumn{2}{|c|}{ Exchange-value side Use-value side } & \\
\hline Organisation of work & Labour power & Labouring capacity & $\begin{array}{l}\text { Analytical } \\
\text { dimensions }\end{array}$ \\
\hline \multicolumn{3}{|c|}{ Object of work / instruments of work - (immaterial) materiality } & \multirow{2}{*}{$\begin{array}{l}\text { Empirical } \\
\text { dimensions }\end{array}$} \\
\hline \multicolumn{3}{|c|}{ Work action - (non physical) corporeality } & \\
\hline \multirow[t]{2}{*}{$\begin{array}{l}\text { - Company organisation } \\
\text { - Internal and inter-firm } \\
\text { cooperation } \\
\text { - Local / global } \\
\text { - Value chain formations } \\
\text { - Production systems } \\
\text { - Re-engineering } \\
\ldots\end{array}$} & $\begin{array}{l}\text { - Formal qualifications } \\
\text { - Performance/control } \\
\text { - Employment } \\
\text { - Subsumption } \\
\text { - Objectifying work action } \\
\text { - } \ldots\end{array}$ & $\begin{array}{l}\text { - Experiential skills } \\
\text { - Individual modes of } \\
\text { action } \\
\text { - Capabilities and experi- } \\
\text { ence } \\
\text { - Autonomy } \\
\text { - Subjectifying work action } \\
\text { - Sediment of biographical } \\
\text { - experiences } \\
\text { - Non-objectifiable genu- } \\
\text { ine living knowledge } \\
\text { - ... }\end{array}$ & $\begin{array}{l}\text { Empirical } \\
\text { manifestations }\end{array}$ \\
\hline & $\begin{array}{l}\text { Formalised, objectified } \\
\text { scientific-based knowledge }\end{array}$ & $\begin{array}{l}\text { Objectifiable parts of living } \\
\text { knowledge }\end{array}$ & $\begin{array}{l}\text { Transformative } \\
\text { dynamics within } \\
\text { the subject }\end{array}$ \\
\hline
\end{tabular}

Table 1: Analytical concept of labouring capacity

\section{Conclusion: Labouring Capacity in Digital Times}

Humans develop labouring capacity constantly through their life course, applying subjectifying action to all environments they encounter and embracing all dimensions of reality in their every-day life within and beyond what we today call the work place. Hence, labouring capacity is not only historically concrete but always more than a unique situation, a single task or a specific job demands to adopt. This fact and the embodied and immanent qualitative nature of labouring capacity makes it a potentially interminable well for creativity, out of the ordinary solutions, and ad hoc improvisation-a truly genuine potential of our species-being, not at all reserved for the so-called creative class (Florida 2012). Labouring capacity could be seen as a human potential that capitalism relies on without understanding it, exploits it without being able to quantify, and neglects even when economic logic thrives to unfold it (Pfeiffer 2014).

The specific nature of subjectifying abilities, and the deeply embodied thus dynamically adopting core of labouring capacity make this ability not only resistant to automation but also specifically relevant for coping with complexities that arise with every new level of automation. We see these developments not only in environments of material production (Böhle 1994 and 2011; Pfeiffer et al. 2010b), but also in mere digital forms of automation (Pfeiffer 1999). Recently we see an arising debate on what I would call automation 4.0, discussing new ICT usage scenarios and their potential for changing work, economy and society for the better or the worse. Intelligent algorithms combined with embedded systems, cloud availability and Big Data challenge our perspective on the human-machine interaction and the question whether we face a new division of labour (Levy and Murnane 2005) beyond today's state of the art computation (Brynjolfsson and Hitt 2000; Brynjolfsson and McAfee 2014). From the perspective of labouring capacity there is no doubt that new forms of human-machine interaction will arise in the years to come; there will be new levels and a not known before quality of digital automation. But we will see new phenomena of the good old productivity paradox (Brynjolfsson 1993; Aral et al. 2012). And, we will also see accordingly developed labouring capacity, necessarily applied and expressed in this highly complex environment of more and 
more layers of digitally objectified labour. Labouring capacity is so much an indispensable quality the more realms of everyday life are object to economical abstractification. Hence in the light of future developments of automation 4.0 labouring capacity more than ever will prove its analytical worth for critical analysis of digital capitalism.

When labouring capacity is taken to the utmost and the potential of this capacity is always more than is ever demanded of the individual in a particular stage of life and historical setting, the change of perspective toward what Negt and Kluge call the abandoned and marginal that is not yet filled up with analytical work alone is a critique (Negt and Kluge 1993b, 93). Lefebvre argues congenially:

Everyday life, in a sense residual, defined by 'what is left over' after all distinct, superior,
specialized, structured activities have been singled out by analysis, must be defined as a
totality. Considered in their specialization and their technicality, superior activities leave a
'technical vacuum' between one another, which is filled up by everyday life. Everyday life
is profoundly related to all activities, and encompasses them with all their differences and
their conflicts; it is their meeting place, their bond, their common ground. And it is in eve-
ryday life that the sum total of relations which make the human-and every human be-
ing-a whole takes its shape and its form. In it are expressed and fulfilled those relations
which bring into play the totality of the real, albeit in a certain manner which is always par-
tial and incomplete: friendship, comradeship, love, the need to communicate, play, etc.
The substance of everyday life- 'human raw material' in its simplicity and richness-
pierces through all alienation and establishes 'disalienation'. If we take the words 'human
nature' dialectically and in their full meaning, we may say that the critique of everyday life
studies human nature in its concreteness (Lefebvre 1991, 97).

While Lefebvre here aims at everyday life beyond capitalistic labour but nonetheless determined by its societal texture (e.g. leisure time, city life), Negt and Kluge (1993) in Geschichte und Eigensinn plead for an analytical acknowledgement of the non-commoditised qualities within capitalistic labour. While labouring capacity can be understood as the theoretical dimension to analytically embrace these dialectically contrary qualities, subjectifying work action serves as the appropriate concept to grasp its phenomenon empirically.

In attempting to develop labouring capacity as dialectical counterpart to labour power inherent in the subject as a key analytical level for digitised work, I hope to have contributed something to the critical perspective on digitized work. Beyond this, labouring capacity, through the empirical phenomenal levels introduced, is an empirically recordable and operationable category which, through its conceptually designed look at the living and not fully subsumable 'other,' opens sociological analysis up again to an emancipation-oriented perspective geared toward manoeuvring autonomy. In the more general version of labouring capacity developed here, which does not limit its emergence to a specific social sphere beyond paid labour, it should become feasible simultaneously to dock the concept of labouring capacity as a current, operationable category for research within and outside paid labour. Even if the analytical concept presented here is deliberately limited to the labour sociological perspective and hence to the capture of (digitised) labour, the labour capacity category could, through the use-value oriented empirical phenomenal level, prove itself in application both to the employment as well as the private sphere-but even more so in the grey area of various boundary-dissolving processes shifting back and forth between these poles. There is no one labouring capacity, there is instead an infinite number of manifestations of labouring capacity. From the labour sociological viewpoint, labouring capacity appears as the category that makes the state and evolution of work quantitatively capturable. The (re)discovery of labouring capacity therefore readily suggests itself as an operationable and hence useful analytical category for social research, particularly in an era when work is undergoing dynamic qualitative change by digitisation. 


\section{References}

Abelson, Hal, Ken Ledeen, and Harry Lewis. 2008. Blown to Bits: Your Life, Liberty, and Happiness After the Digital Explosion. Upper Saddle River: Addison Wesley.

Aral, Sinan, Erik Brynjolfsson, and Marshall van Alstyne. 2012. Information, Technology and Information Worker Productivity. Information Systems Research Journal (3). Accessed April 4, 2014 http://archive.nyu.edu/bitstream/2451/27758/2/CPP-10-06.pdf

Arendt, Hannah. 1998. The Human Condition. Chicago River: University of Chicago Press.

Böhle, Fritz. 1994. Relevance of Experience-based Work in Modern Processes. Al \& Society. Journal of Human Centered Systems and Machine Intelligence 8 (3): 207-215.

Böhle, Fritz. 2013. 'Subjectifying Action' as a Specific Mode of Working With Customers. In Customers At Work-New Perspectives on Interactive Service Work, edited by Wolfgang Dunkel and Frank Kleemann, 149-74. Basingstoke Yorkork: Palgrave Macmillanago Press.

Böhle, Fritz and Brigitte Milkau. 1988. Computerised Manufacturing and Empirical Knowledge. Al \& Society. Journal of Human Centered Systems and Machine Intelligence 2: 235-243.

Böhle, Fritz. 2011. Management of Uncertainty. A Blind Spot in the Promotion of Innovations. In Enabling Innovation. Innovative Capability-German and International Views, edited by Sabina Jeschke, Ingrid Isenhardt, Frank Hees and Sven Tantrow, 17-30. Berlin, Heidelberg: Springer.

Bottomore, Tom, Laurence Harris, V. G. Kiernan and Ralph Miliband. 1998. A Dictionary of Marxist Thought. Oxford, Malden: Blackwell.

Brynjolfsson, Erik. 1993. The Productivity Paradox of Information. Communications of the Association for Computing Manufacturing 36 (12): 67-77.

Brynjolfsson, Erik and Lorin M. Hitt. 2000. Beyond Computation: Information Technology, Organizational Transformation and Business Performance. Journal of Economic Perspectives 14 (4): 23-48.

Brynjolfsson, Erik and Andrew McAfee. 2014. The Second Machine Age: Work, Progress, and Prosperity in a Time of Brilliant Technologies. New York, London: W. W. Norton \& Co.

Caldwell, John T. 2009. Hive-sourcing is the New Out-sourcing: Studying Old (industrial) Labor Habits in New (consumer) Labor Clothes. Cinema Journal 49 (1): 160-167.

Castells, Manuelegri, Antonio. 2000. The Rise of the Network Society: Economy, Society and Culture. Chichester: Wiley-Blackwell.

Douai, Adolph. 1887. Labor and Work: Labor is the Enemy of Human Dignity. Workmen's Advocatecetions and Society 3 (17): 1-2.

Engels, Friedrich. 1885. How Not to Translate Marx. Accessed January 4, 2014. http://www.marxists.org/archive/marx/works/1885/11/translating-marx.htm

Engels, Friedrich. 1975. Wie man Marx nicht übersetzen sollte. MEW Bd. 21. Acessed January 4, 2014. http://www.mlwerke.de/me/me21/me21_229.htm

Florida, Richard. 2012. The Rise of the Creative Class Revisited. Philadelphia: Basic.

Fuchs, Christian 2011. The Contemporary World Wide Web: Social Medium or New Space of Accumulation? In The Political Economies of Media. the Transformation of the Global Media Industries, edited by Dwayn Winseck and Da Yong Jin. London: Bloomsbury Publishing PLC, 201-220.

Fuchs, Christian. 2013. Capitalism or Information Society? The Fundamental Question of the Present Structure of Society. European Journal of Social Theory 16 (4): 413-434.

Fuchs, Christianh. 2012. Dallas Smythe Today - the Audience Commodity, the Digital Labour Debate, Marxist Political Economy and Critical Theory. Prolegomena to a Digital Labour Theory of Value. tripleC. Journal for a Global Sustainable Information Society 10 (2): 692-740.

Fuchs, Christian and Sebastian Sevignani. 2013. What is Digital Labour? What is Digital Work? What's Their Difference? and Why Do These Questions Matter for Understanding Social Media? Digital Labour Theory of Value. tripleC. Journal for a Global Sustainable Information Society 11 (2): 237-293.

Fuchs, Christian. 2012. Class and the Exploitation on the Internet. In Digital Labor: the Internet as Playground and Factory, edited by Trebor Scholz and Da Yong Jin, 211-224. New York, Oxon: Routledge.

Gulli, Bruno. 2006. Labor of Fire: the Ontology of Labor Between Economy and Culture Socialism. Philadelphia: Temple University Press.

Hardt, Michael and Antonio Negri. 2000. Empire. Cambridge: Harvard University Press.

Hardt, Michael and Antonio Negri. 2009. Commonwealth. Cambridge: Harvard University Press.

Huws, Ursula. 1999. Material World: the Myth of the Weightless Economy. Socialist Register 35: 2955. 
Huws, Ursula. 2014. The Underpinnings of Class in the Digital Age: Living, Labour and Value. Socialist Register 50 (1).

Hyde, Lewis. 2007. The Gift: Creativity and the Artist in the Modern World. New York, Toronto: Vintage.

Israel, Joachim. 1979. Language of Dialectics and the Dialectics of Language. Copenhagen: Munksgaard.

Jameson, Frederic. 1988. On Negt and Kluge. October 46: 151-177.

Lash, Scott. 2002. Critique of Information. London, Thousands Oaks, New Delhi: Sage.

Lash, Scott. 1984. The Militant Worker. Class and Radicalism in France and America. Cranbury, NJ: Associated University Press.

Lefebvre, Henri. 1991. Critique of Everyday Life. Vol. 1. London, New York: Verso.

Levy, Frank and Richard J. Murnane (2005). The New Division of Labor: How Computers are Creating the Next Job Market. Princeton, Oxfordshire: Russell Sage.

Marcuse, Herbert. 1973. On the Philosophical Foundation of the Concept of Labor in Economics. Telos (16): 9-37.

Marx, Karl. 1842. Proceedings of the Sixth Rhine Province Assembly. First Article. Debates on Freedom of the Press and Publication of the Proceedings of the Assembly of the Estates. MECW Vol. 1. Accessed January 4, 2014. http://www.marxists.org/archive/marx/works/cw/volume01/index.htm

Marx, Karl. 1844. Economic and Philosophical Manuscripts of 1844. MECW Vol. 3. Accessed January 4, 2014. http://www.marxists.org/archive/marx/works/cw/volume03/index.htm

Marx, Karl. 1845. Theses on Feuerbach. MECW Vol. 5. Accessed January 4, 2014. http://www.marxists.org/archive/marx/works/1845/theses/original.htm

Marx, Karl. 1857. (Grundrisse) Outlines of the Critique of Political Economy. Accessed January 4, 2014. http://www.marxists.org/archive/marx/works/1857/grundrisse/

Marx, Karl. 1859. Economic Manuscripts of 1857-58 (Second Part of the Grundrisse and the Contribution to the Critique of Political Economy 1859), MECW Vol. 29. Accessed January 4, 2014. http://www.marxists.org/archive/marx/works/cw/volume29/index.htm

Marx, Karl. 1887. Capital I. A Critique of Political Economy. MECW Vol. 35. Accessed January 4, 2014. http://www.marxists.org/archive/marx/works/cw/volume29/index.htm

Marx, Karl. 1993. Grundrisse. Outlines of the Critique of Political Economy. London, New York: Penguin.

Musto, Marcello. 2008. Karl Marx's Grundrisse: Foundations of the Critique of Political Economy 150 Years Later. London, New York: Routledge.

Negri, Antonio. 1991. Marx Beyond Marx: Lessons on the Grundrisse. New York, London: Autonomedia.

Negt, Oskar and Alexander Kluge. 1993a. Public Sphere and Experience: Toward an Analysis of the Bourgeois and Proletarian Public Sphere. Minneapolis: University of Minnesota Press.

Negt, Oskar, and Alexander Kluge. 1993b. Geschichte und Eigensinn. Bd. 1: Entstehung der Industriellen Disziplin aus Trennung und Enteignung. Frankfurt: Suhrkamp.

Pfeiffer, Sabine. 1999. Ignored and Neglected-Work in Cybersociety. In Exploring Cybersociety. Social, Political, Economic and Cultural Issues, Vol. 2, edited by John Armitage and Joan Roberts. Newcastle: University of Northumbrian.

Pfeiffer, Sabine. 2004. Arbeitsvermögen. Ein Schlüssel zur Analyse (reflexiver) Informatisierung. Wiesbaden: VS Verlag für Sozialwissenschaften.

Pfeiffer, Sabine. 2013. Web, Value and Labour. Work Organisation, Labour and Globalisation 7 (1): 12-30.

Pfeiffer, Sabine. 2014. Social Media in Organizations: Fostering Creativity and CommunicationChanging Culture in the Process. In Communication, Culture and Creativity: Reframing the Relations of Media, Knowledge, and Innovation in Society by Hubert Knoblauch, Mark Jacobs and René, 247-266. Frankfurt, Berlin, New York: Lang.

Pfeiffer, Sabine, Petra Schütt and Daniela Wühr. 2010a. Innovation, Market, NetworksInterdependencies, Synergies and Contradictions in Technical Innovation Processes. In Markets as Networks, edited by Tanya Chavdarova, Petya Slavova and Svetla Stoeva, 165-180. Sofia: St. Kliment University Press.

Pfeiffer, Sabine, Petra Schütt, and Daniela Wühr. 2010b. Standardization of Production and Development Processes-Blessing or Curse? in Technical Innovation Processes. In Sixteenth International Working Seminar on Production Economics, edited by Robert W. Grubbström and Hans H. Hinterhuber, 411-422. Innsbruck. 
Rainie, Lee and Barry Wellman. 2012. Networked: the New Social Operating System. Cambridge: MIT Press.

Schiller, Dan. 2000. Digital Capitalism: Networking the Global Market System. Cambridge, London: MIT Press.

Schiller, Dan. 2011. Power Under Pressure: Digital Capitalism In Crisis. International Journal of Communication 5: 924-941.

Schmiede, Rudi. 2006. Knowledge, Work and Subject in Informational Capitalism. In Social Informatics-An Information Society for All? edited by Jacques Berleur, Markku I. Nurminen and John Impagliazzo, 333-354. New York: Springer.

Scholz, Trebor. 2012. Digital Labor: The Internet as Playground and Factory. New York: Routledge.

\section{About the Author}

Sabine Pfeiffer

Prof. Dr. habil. Sabine Pfeiffer worked in the automotive and manufacturing industry as a toolmaker and in technical support for CNC-machines and CAD/CAM-systems for years before she studied sociology, psychology, and philosophy at the University of Hagen. In 2003 her doctoral thesis about labouring capacity (Arbeitsvermögen) as a category for the critical analysis of informatisation was marked outstanding. Sabine Pfeiffer worked at the Institute for Social Science Research (ISF Munich) since 1998 as a senior research fellow, and still serves there as a member of the governing board. Since her habilitation on the dialectics of corporeality and materiality in 2009, she held a professorship for innovation at the University for Applied Sciences Munich from 2010 to 2014, when she was appointed to the chair of sociology at the University of Hohenheim. 